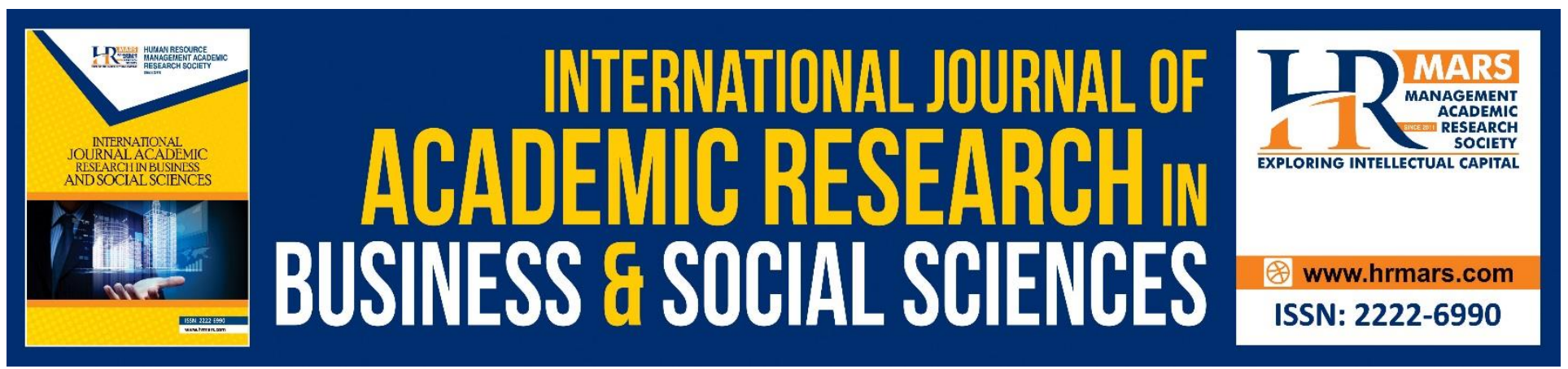

\title{
The Prevalence of Cyber-Counselling: A Systematic Literature Review on Effectiveness and Preferences
}

\author{
Zaida Nor Zainudin, Alia Sarah Asri, Mansor Abu Talib, Siti Aishah Hassan, \\ Nor Aniza Ahmad, Yusni Mohamad Yusop
}

To Link this Article: http://dx.doi.org/10.6007/IJARBSS/v10-i10/7897 DOI:10.6007/IJARBSS/v10-i10/7897

Received: 02 August 2020, Revised: 27 August 2020, Accepted: 17 September 2020

Published Online: 29 October 2020

In-Text Citation: (Zainudin, et. al., 2020)

To Cite this Article: Zainudin, Z. N., Asri, A. S., Abu Talib, M., Hassan, S. A., Ahmad, N. A., \& Yusop, Y. M. (2020). The Prevalence of Cyber-Counselling: A Systematic Literature Review on Effectiveness and Preferences . International Journal of Academic Research in Business and Social Sciences. 10(10), 731-751.

Copyright: @ 2020 The Author(s)

Published by Human Resource Management Academic Research Society (www.hrmars.com)

This article is published under the Creative Commons Attribution (CC BY 4.0) license. Anyone may reproduce, distribute, translate and create derivative works of this article (for both commercial and non-commercial purposes), subject to full attribution to the original publication and authors. The full terms of this license may be seen

at: http://creativecommons.org/licences/by/4.0/legalcode

\section{Vol. 10, No. 10, 2020, Pg. 731 - 751}

Full Terms \& Conditions of access and use can be found at http://hrmars.com/index.php/pages/detail/publication-ethics 


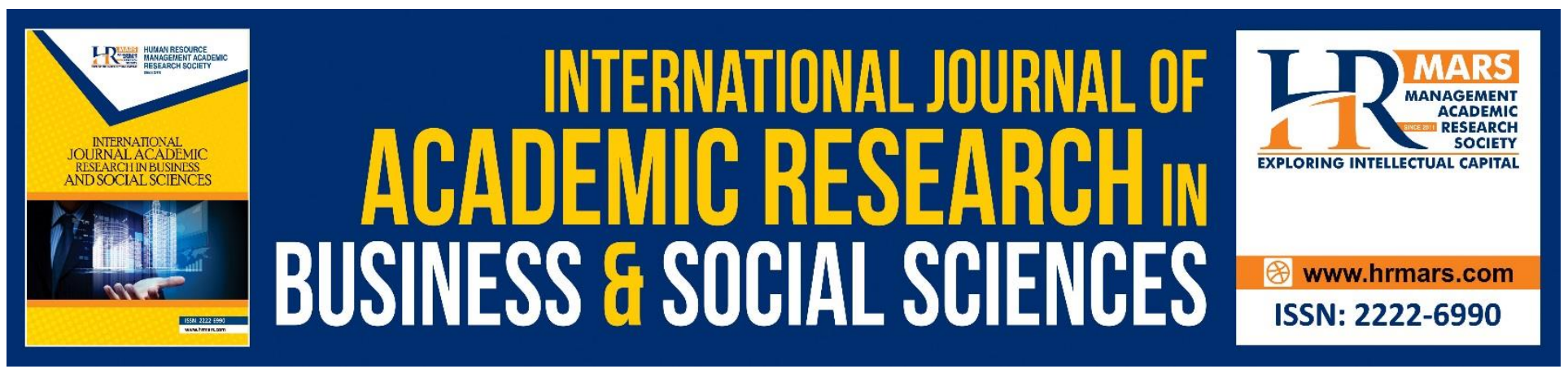

\title{
The Prevalence of Cyber-Counselling: A Systematic Literature Review on Effectiveness and Preferences
}

\author{
Zaida Nor Zainudin, PhD, Alia Sarah Asri, Mansor Abu Talib, \\ PhD, Siti Aishah Hassan, PhD, Nor Aniza Ahmad, PhD, Yusni \\ Mohamad Yusop, PhD
}

Faculty of Educational Studies, University Putra Malaysia, Serdang Selangor. Malaysia Email: zaidanor@upm.edu.my,gs53296@student.upm.edu.my,mansorat@upm.edu.my, siti_aishahh@upm.edu.my,nor_aniza@upm.edu.my, yusni_my@upm.edu.my

\begin{abstract}
Cyber-counselling, among its other names, is not at all new to the counselling field. Along with the emergence and advancement of computer-assisted technology, internet, and information and communications technology (ICT), the counselling field has also benefited from the use of online services in providing counselling to all. It is no longer a rare topic to discuss, but now an important area of study and service that has the ability to reach out to all people across the globe. Hence the purpose of this systematic literature review is to explore and discuss the prevalence of cybercounselling in reaching out to all possible clients and improving counselling experiences and outcomes to all. Journal articles were selected primarily from the use of SCOPUS database for the purpose of this review and its main objectives. The searching process started with a list of keywords "cyber counselling", "online counselling", "e-counselling", "e-therapy" and "face-to-face counselling". The inclusion and exclusion criteria applied with limited from the year 2012 to 2019. The subject areas selected were Psychology, Social Sciences and Arts and Humanities. A total of 22 articles were selected and included in this review study. The limitations in the use and delivery of online counselling were also reviewed which finally led to the discussion of implications of online counselling as an alternative method to counselling.
\end{abstract}

Keywords: Cyber-Counselling, Effectiveness, Preferences, Prevalence.

\section{Introduction}

Cyber-counselling, also called as e-counselling, web-counselling and e-therapy (Zainudin \& Yusop, 2018), has dated all the way back to the early 1960s with the development of computer. National Board for Certified Counselors defined cyber-counselling as "the practice of professional counselling and information delivery that occurs when client(s) and counsellor are in separate or remote locations and utilize electronic means to communicate over the Internet"' (Mishna, et al., 2015). 
INTERNATIONAL JOURNAL OF ACADEMIC RESEARCH IN BUSINESS AND SOCIAL SCIENCES Vol. 10, No. 10, 2020, E-ISSN: 2222-6990 @ 2020 HRMARS

The rapidly increasing rate in the use of internet and ICT among Millennium generation has become a norm for all where it assists in obtaining information or in seeking help with health and relationships (Suzuki \& Calzo, 2004). Simultaneously, the internet has provided counsellors with multiple methods in building counselling relations with clients and these include the use of e-mails, online chatroom, video conferencing and online support group (Stefan \& David, 2013; Murphy et al., 2009).

According to Eisenberg et al. (2007); Al-krenawi et al. (2009); Heflinger and Hinshaw (2010) and Wong et al. (2018), the stigma among the Asian societies towards mental health problems are hindering some affected individuals from seeking for help. This, including the norms in Asian cultures that are less inclined towards self-disclosure, may be causing the 2.8 to 10 million individuals in Malaysia (Crabtree \& Chong, 2000; Wong, et al., 2018), to not choose to seek for mental health support and help. This situation is similar as to the 'negation effect' (Glasheen, et al, 2016) which is experienced by individuals who are facing severe psychological issues such as depression and social anxiety but are refusing to seek professional help. This negation effect and stigma on mental health problems, however, are able to make cyber-counselling a more viable and convenient option for affected individuals who may not consider seeking help through face-to-face counselling.

For this particular reason, the online counselling is seen to be prevalent as a good alternative to faceto-face counselling for multiple reasons. The effectiveness in the use of both counselling methods are shown to be as equal (Stefan \& David, 2013; Dunn, 2012; Holmes \& Foster, 2012) while the preferences toward either counselling methods are varied with slight or no significant differences identified. The preferences toward using online counselling can be explained by the sense of anonymity, privacy and control that such counselling method has to offer the clients with (Dunn, 2012; Campbell \& Glasheen, 2012). A study by Glasheen et al,. (2015) among secondary school students showed that over $80 \%$ of the students are willing and preferred to use online counselling services if made available at school for different reasons such as their anonymity, as previously mentioned.

Hence, this paper is written to explore the prevalent use of cyber-counselling services to all possible clients and to address the effectiveness and preferences toward such services over more traditional counselling methods such as face-to-face counselling. Even though the effectiveness of both counselling methods shows no significant differences, reviewer wished to explore the factors that are making online counselling such a prevalent method to counselling and help-seeking in this technological era. This review paper also discussed the limitations that the reviewer believed to be challenging the use and preferences of both clients and counsellors toward using online counselling, which will later allow for continual improvement in overall counselling services.

The objective of this review is to investigate and explore the prevalent use of cyber-counselling. Hence the questions below will provide some of the main ideas and contexts that will be reviewed in this study.

1. What are the statistics of effectiveness and preferences toward cyber-counselling?

To study this, reviewer will provide statistical data acquired from literature readings which illustrated both the effectiveness and preferences toward online counselling.

2. What is the prevalence that cyber-counselling services have over face-to-face counselling? 
INTERNATIONAL JOURNAL OF ACADEMIC RESEARCH IN BUSINESS AND SOCIAL SCIENCES

Vol. 10 , No. 10, 2020, E-ISSN: 2222-6990 @ 2020 HRMARS

The focus of this review is to discuss and explore some of the factors that make cyber-counselling an effective and preferable, alternative counselling method.

3. What are the patterns of factors that make prevalent of cyber-counselling as alternative and preferable method of counselling?

The factors asserted in the literatures used shall be concluded as the main factors that are making cyber-counselling method preferable to some.

4. What are the limitations that cyber-counselling services have over face-to-face counselling?

To call for more improvement in the use of cyber-counselling services, some of their limitations will be provided in this paper by reviewer.

\section{Methodology}

The systematic literature review was first initiated with the key word "cyber-counselling" and "etherapy". Some other key words were also included so to limit the literatures to a smaller number that was further filtered to derive suitable and appropriate literatures. Hence, the objectives of this systematic literature review serves as a guide when searching for literatures that are appropriate to the main context in this review paper.

\section{The Search Strategy}

Journal articles were selected primarily from the use of SCOPUS database for the purpose of this review and its main objectives. The searching process started with a list of keywords "cyber counselling", "online counselling", "e-counselling", "e-therapy" and "face-to-face counselling". A complete list of keywords or search string for this study is tabulated in Table 2. The keywords used were able to extract as many as 117 articles in the initial searching process. Such reasonable number of articles identified were possibly due to the specific list of keywords used, while at the same time may also be due to the lack of research conducted on the topic.

Next, the search was limited from the year 2012 to 2019 as to review some of the most recent journal articles publication, where it was able to identify 81 articles. Then, the identified articles were also screened according to their document or literature type by excluding book, book chapters, review article and conference proceedings or articles. The number of articles remained for selection after this exclusion process was 59 articles. Afterwards, only subject areas Psychology, Social Sciences and Arts and Humanities were included in the article selection where articles selected were also in English, which finally resulted to 51 articles. This searching method is known as to be the inclusion and exclusion criteria, which can be better described in Table 1, in order to search for the most appropriate literature reading for this review.

Finally, the remaining articles left were all reviewed for eligibility according to their titles and abstract those were relatable to the content of this study. In the final selection process, a total of 22 articles were selected and included in this review study. A complete article selection process is as shown in the flow of systematic review process in Figure 1. 
INTERNATIONAL JOURNAL OF ACADEMIC RESEARCH IN BUSINESS AND SOCIAL SCIENCES Vol. 10, No. 10, 2020, E-ISSN: 2222-6990 @ 2020 HRMARS

Table 1. Inclusion and Exclusion Criteria

\begin{tabular}{lll}
\hline \hline Criterion & Eligibility (Inclusion) & Exclusion \\
\hline Publication years & $2012-2019$ & $<2012$ \\
Document & Research Article & Book, book chapter, review \\
& & paper, conference paper \\
Language & English & Non-English \\
Subject Area & Psychology, Social Sciences, & Computer Science, Medicine \\
& Arts \& Humanities & \\
\hline \hline
\end{tabular}

Table 2. Search string used for systematic literature review process

\begin{tabular}{ll}
\hline \hline Database & Key terms used \\
\hline Scopus & "Cyber counselling" OR “cyber counseling" OR “online counselling" OR “online \\
& $\begin{array}{l}\text { counseling" OR “E-counselling" OR “E-counseling" OR “E-therapy AND "Face-to-Face } \\
\text { counselling" OR "face-to-face counseling" }\end{array}$ \\
\hline \hline
\end{tabular}


INTERNATIONAL JOURNAL OF ACADEMIC RESEARCH IN BUSINESS AND SOCIAL SCIENCES

Vol. 10, No. 10, 2020, E-ISSN: 2222-6990 @ 2020 HRMARS
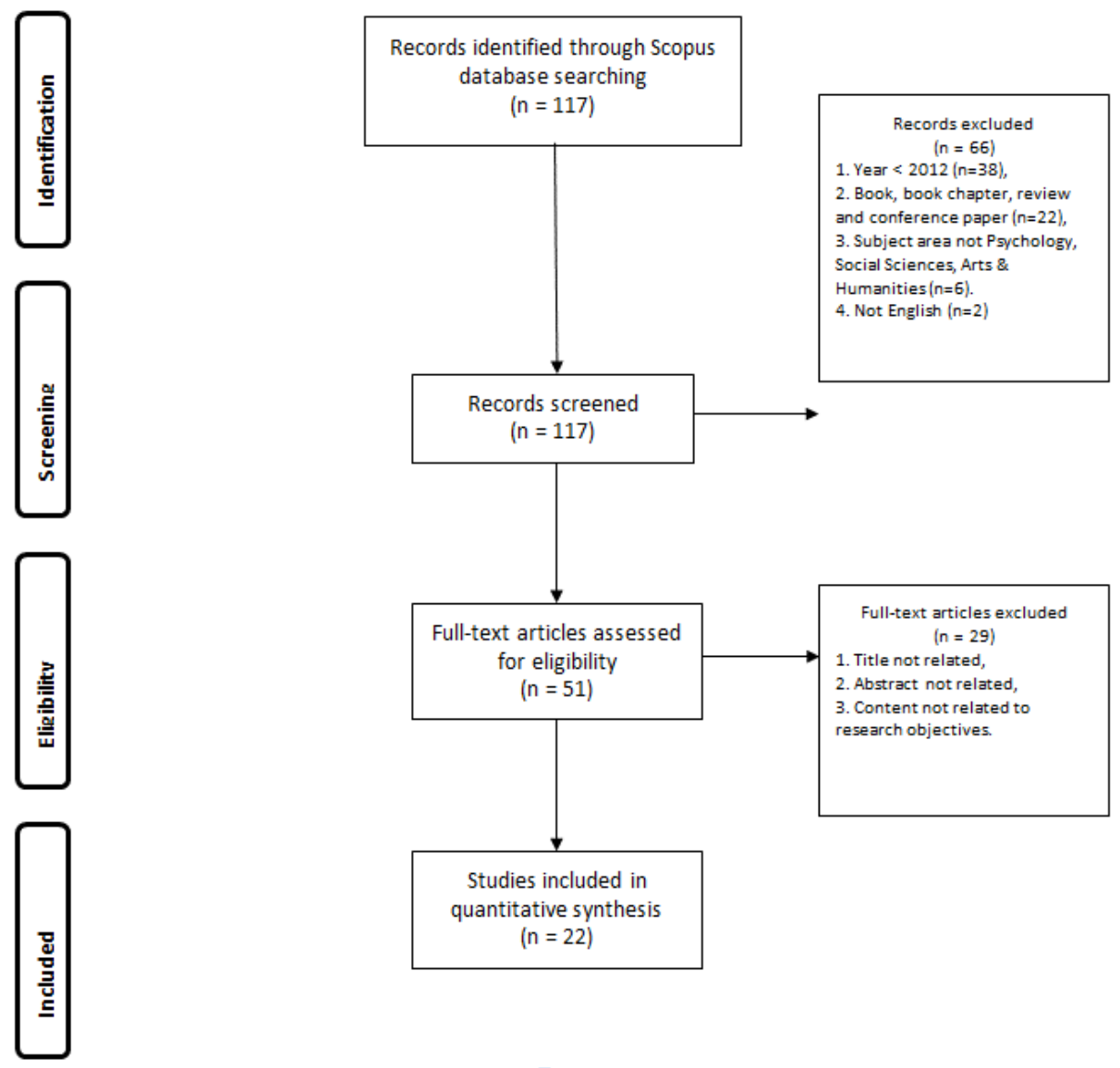

Figure 1: Flow chart of systematic literature review

\section{Findings}

The selected journal articles from the search strategy are summarized as shown in Table 3 . The literatures are presented by their authors, publication years, title of the articles in the journal, sample of the study conducted and finally the findings in each literature that are relevant to the objectives of this systematic literature review.

Table 3. Summary of selected literatures

\section{Author (Year) Title of Journal Sample Relevant Findings}

1 Ballesteros, J. L., Attitudes toward Online 231 college The research showed \& Hilliard, R. C. Counseling. students. (2016). U.S.-

Based Latina/O

College

Students'
Age: $18-55$

years

Male: 85

Female: 146 fairly positive attitudes

of US-based Latina/o college students toward both online and face-toface counselling. While there are slightly more preferences toward 


\begin{tabular}{|c|c|c|c|c|}
\hline & & & & $\begin{array}{l}\text { face-to-face counselling, } \\
\text { they are less stigma } \\
\text { towards online } \\
\text { counselling which } \\
\text { explains the positive } \\
\text { attitudes. }\end{array}$ \\
\hline 2 & $\begin{array}{l}\text { Bathje, G. J., } \\
\text { Kim, E., Rau, E., } \\
\text { Bassiouny, M. } \\
\text { A., \& Kim, T. } \\
\text { (2014). }\end{array}$ & $\begin{array}{l}\text { Attitudes toward Face- } \\
\text { to-Face and Online } \\
\text { Counseling: Roles of } \\
\text { Self-Concealment, } \\
\text { Openness to Experience, } \\
\text { Loss of Face, Stigma, and } \\
\text { Disclosure Expectations } \\
\text { among Korean College } \\
\text { Student }\end{array}$ & $\begin{array}{l}228 \text { volunteered } \\
\text { students who } \\
\text { enrolled in } \\
\text { psychology } \\
\text { courses } \\
\text { Male: } 107 \\
\quad \text { Female: } 121\end{array}$ & $\begin{array}{l}\text { Research showed less } \\
\text { negative impact of } \\
\text { stigma on online } \\
\text { counselling and a slightly } \\
\text { or neutral attitudes } \\
\text { toward online } \\
\text { counselling due to self- } \\
\text { disclosure expectations. }\end{array}$ \\
\hline 3 & $\begin{array}{l}\text { Blake-Buffini, K., } \\
\text { \& Gordon, M. } \\
(2014)\end{array}$ & $\begin{array}{l}\text { One-to-one support for } \\
\text { crisis intervention using } \\
\text { online synchronous } \\
\text { instant messaging: } \\
\text { evaluating working } \\
\text { alliance and client } \\
\text { satisfaction }\end{array}$ & $\begin{array}{l}78 \text { participants } \\
\text { who have been } \\
\text { diagnosed with } \\
\text { mental health } \\
\text { condition } \\
\text { Age: } 18 \text { years } \\
\text { and over } \\
\text { Male: } 13 \\
\text { Female: } 65\end{array}$ & $\begin{array}{l}\text { Study indicated working } \\
\text { alliance as a predictor to } \\
\text { clients' satisfaction, } \\
\text { whereby clients who } \\
\text { were previously } \\
\text { diagnosed with mental } \\
\text { health issues show } \\
\text { lower level of } \\
\text { satisfaction from online } \\
\text { counselling as compared } \\
\text { to offline (face-to-face) } \\
\text { counselling. }\end{array}$ \\
\hline 4 & $\begin{array}{l}\text { Campbell, M. A., } \\
\text { \& Glasheen, K. } \\
(2012)\end{array}$ & $\begin{array}{l}\text { The Provision of Online } \\
\text { Counselling for Young } \\
\text { People }\end{array}$ & $\begin{array}{l}\text { Secondary } \\
\text { school students } \\
\text { and school } \\
\text { counsellors }\end{array}$ & $\begin{array}{l}\text { Although the technology } \\
\text { has been a primary } \\
\text { medium of } \\
\text { communication and } \\
\text { information gathering } \\
\text { for youth, the use of } \\
\text { online counselling } \\
\text { services is seen to not } \\
\text { be as much as being } \\
\text { used by adult. }\end{array}$ \\
\hline 5 & $\operatorname{Lan}(2016)$ & $\begin{array}{l}\text { Predictors of Willingness } \\
\text { to Use Cyber Counseling } \\
\text { for College Students } \\
\text { With Disabilities }\end{array}$ & $\begin{array}{l}214 \text { college } \\
\text { students with } \\
\text { disabilities in } \\
\text { universities in } \\
\text { Taiwan. } \\
\text { Age(mean): } \\
21.11 \text { years } \\
\end{array}$ & $\begin{array}{l}\text { Cyber-counselling needs } \\
\text { and cyber-counselling } \\
\text { help-seeking attitudes } \\
\text { serve as determinants } \\
\text { for willingness of college } \\
\text { students with disabilities }\end{array}$ \\
\hline
\end{tabular}




\begin{tabular}{|c|c|c|c|c|}
\hline & & & $\begin{array}{l}\text { Male: } 102 \\
\text { Female: } 112\end{array}$ & $\begin{array}{l}\text { to use cyber-counselling } \\
\text { services. }\end{array}$ \\
\hline 6 & $\begin{array}{l}\text { Cipolletta, S., \& } \\
\text { Mocellin, } \\
\text { (2017) }\end{array}$ & $\begin{array}{l}\text { Online counseling: An } \\
\text { exploratory survey of } \\
\text { Italian psychologists' } \\
\text { attitudes towards new } \\
\text { ways of interaction }\end{array}$ & $\begin{array}{l}388 \text { Italian } \\
\text { licensed } \\
\text { psychologists } \\
\text { Age: } 27-80 \\
\text { years } \\
\text { Male: } 48 \\
\text { Female: } 241\end{array}$ & $\begin{array}{l}\text { Study conducted } \\
\text { indicates that most } \\
\text { respondents, } \\
\text { psychologists who also } \\
\text { had previously provided } \\
\text { online counselling, are } \\
\text { showing positive } \\
\text { attitude and more } \\
\text { favoritism towards using } \\
\text { the online modalities. }\end{array}$ \\
\hline 7 & $\begin{array}{l}\text { Dowling, M. J., \& } \\
\text { Rickwood, D. J. } \\
\text { (2014) }\end{array}$ & $\begin{array}{l}\text { Experiences of } \\
\text { Counsellors Providing } \\
\text { Online Chat Counselling } \\
\text { to Young People. }\end{array}$ & $\begin{array}{l}19 \text { professional } \\
\text { online mental } \\
\text { health clinicians } \\
\text { Male: } 3 \\
\text { Female: } 16\end{array}$ & $\begin{array}{l}\text { The study highlighted on } \\
\text { counsellors' perceptions } \\
\text { on online clients } \\
\text { whereby they have } \\
\text { multiple roles not only } \\
\text { as counsellors, while } \\
\text { also dealing with issues } \\
\text { brought into online that } \\
\text { are mostly much more } \\
\text { serious and complex. }\end{array}$ \\
\hline 8 & Dunn, K. (2012) & $\begin{array}{l}\text { A Qualitative } \\
\text { Investigation into The } \\
\text { Online Counselling } \\
\text { Relationship: To Meet or } \\
\text { Not to Meet, That Is The } \\
\text { Question }\end{array}$ & $\begin{array}{l}13 \text { participants } \\
\text { as clients. } \\
\text { Age: } 19-25 \text { years } \\
\text { Male: } 3 \text {; Female: } \\
10 \\
6 \text { participants as } \\
\text { counsellors. } \\
\text { Male: } 1 \text {; Female: } \\
5\end{array}$ & $\begin{array}{l}\text { Although lacking in } \\
\text { physical presence, } \\
\text { features such as locus of } \\
\text { control, anonymity, } \\
\text { disinhibition and more } \\
\text { time to think in email } \\
\text { counselling are shown to } \\
\text { make online counselling } \\
\text { an alternative } \\
\text { counselling method. }\end{array}$ \\
\hline 9 & $\begin{array}{l}\text { Glasheen, K. J., } \\
\text { Shochet, I., \& } \\
\text { Campbell, M. A., } \\
(2016)\end{array}$ & $\begin{array}{l}\text { Online Counseling in } \\
\text { Secondary Schools: } \\
\text { Would Students Seek } \\
\text { Help by This Medium? }\end{array}$ & $\begin{array}{l}215 \text { secondary } \\
\text { school students } \\
\text { from schools } \\
\text { Male: } 103 \\
\text { Female: } 112\end{array}$ & $\begin{array}{l}\text { The likeness of students } \\
\text { to seek for help through } \\
\text { online counselling are } \\
\text { influenced by factors } \\
\text { such as gender and } \\
\text { levels of psychological } \\
\text { distress. }\end{array}$ \\
\hline 10 & Hanley, T. (2012) & $\begin{array}{l}\text { Understanding the } \\
\text { Online Therapeutic } \\
\text { Alliance through The }\end{array}$ & $\begin{array}{l}15 \text { secondary } \\
\text { school students. } \\
\text { Age: } 11-15 \text { years } \\
\text { Male: } 0\end{array}$ & $\begin{array}{l}\text { Three factors are } \\
\text { examined: initial } \\
\text { engagement, developing } \\
\text { rapport and establishing }\end{array}$ \\
\hline
\end{tabular}


INTERNATIONAL JOURNAL OF ACADEMIC RESEARCH IN BUSINESS AND SOCIAL SCIENCES

\begin{tabular}{|c|c|c|c|c|}
\hline & & $\begin{array}{l}\text { Eyes of Adolescent } \\
\text { Service Users }\end{array}$ & Female: 15 & $\begin{array}{l}\text { control, which influence } \\
\text { client-service match or } \\
\text { therapeutic working } \\
\text { alliances through online } \\
\text { counselling. }\end{array}$ \\
\hline 11 & $\begin{array}{ll}\text { Harris, B., } & \& \\
\text { Birnbaum, } & \text { R. } \\
(2014) & \end{array}$ & $\begin{array}{l}\text { Ethical and Legal } \\
\text { Implications on the Use } \\
\text { of Technology in } \\
\text { Counselling. }\end{array}$ & - & $\begin{array}{l}\text { The study discussed on } \\
\text { the advantages of using } \\
\text { online counselling } \\
\text { modalities where such } \\
\text { advantages } \\
\text { (accessibility, } \\
\text { anonymity, } \\
\text { asynchronous } \\
\text { communication) can } \\
\text { also be their } \\
\text { disadvantages and } \\
\text { barriers to efficient } \\
\text { counselling sessions. }\end{array}$ \\
\hline 12 & $\begin{array}{l}\text { Holmes, C., \& } \\
\text { Foster, V. (2012) }\end{array}$ & $\begin{array}{l}\text { A Preliminary } \\
\text { Comparison Study of } \\
\text { Online and Face-to-Face } \\
\text { Counseling: Client } \\
\text { Perceptions of Three } \\
\text { Factors }\end{array}$ & $\begin{array}{l}50 \text { counselling } \\
\text { participants } \\
\text { Age: } 18 \text { and } \\
\text { above } \\
\text { Male: } 11 \\
\text { Female: } 39\end{array}$ & $\begin{array}{l}\text { The research analyzed } \\
\text { that the social presence } \\
\text { and working alliance } \\
\text { constructs in online } \\
\text { counselling are at least } \\
\text { similar to clients' } \\
\text { experiences with face- } \\
\text { to-face counselling. }\end{array}$ \\
\hline 13 & $\begin{array}{l}\text { Holmes, C. M., \& } \\
\text { Kozlowski, K. A. } \\
(2015)\end{array}$ & $\begin{array}{l}\text { A Preliminary } \\
\text { Comparison of Online } \\
\text { and Face-to-Face } \\
\text { Process Groups. }\end{array}$ & $\begin{array}{l}\text { Participants, } \\
\text { who are } \\
\text { counselling } \\
\text { master students, } \\
\text { are divided into } \\
\text { two groups: } 31 \\
\text { in face-to-face } \\
\text { and } 12 \text { in online } \\
\text { Male: } 6 \text { \& } 2 \\
\text { Female: } 25 \& 10\end{array}$ & $\begin{array}{l}\text { The study was } \\
\text { conducted with two } \\
\text { groups of participants: } \\
\text { online and face-to-face } \\
\text { group counselling. } \\
\text { Results obtained } \\
\text { indicated that although } \\
\text { working alliance } \\
\text { between the two groups } \\
\text { does not differ } \\
\text { significantly, participants } \\
\text { do feel the lack of group } \\
\text { safety, emotional } \\
\text { relatedness and social } \\
\text { presence in online } \\
\text { setting. }\end{array}$ \\
\hline 14 & $\begin{array}{l}\text { Wong, K. P., } \\
\text { Bonn, G., Tam, C. }\end{array}$ & $\begin{array}{l}\text { Preferences for Online } \\
\text { and/or Face-to-Face }\end{array}$ & $\begin{array}{l}409 \text { students } \\
\text { from six }\end{array}$ & $\begin{array}{l}\text { The study indicated a } \\
\text { slight preference toward }\end{array}$ \\
\hline
\end{tabular}


INTERNATIONAL JOURNAL OF ACADEMIC RESEARCH IN BUSINESS AND SOCIAL SCIENCES Vol. 10, No. 10, 2020, E-ISSN: 2222-6990 @ 2020 HRMARS

\begin{tabular}{|c|c|c|c|c|}
\hline & $\begin{array}{l}\text { L. \& Wong, C. P. } \\
(2018)\end{array}$ & $\begin{array}{l}\text { Counseling among } \\
\text { University Students in } \\
\text { Malaysia }\end{array}$ & $\begin{array}{l}\text { universities in } \\
\text { Malaysia. } \\
\text { Age: } 16-35 \text { years } \\
\text { Male: } 170 \\
\text { Female: } 239\end{array}$ & $\begin{array}{l}\text { face-to-face counselling } \\
\text { although both } \\
\text { counselling methods } \\
\text { were viewed positively. }\end{array}$ \\
\hline 15 & $\begin{array}{l}\text { Mishna, F., Bogo, } \\
\text { M., \& Sawyer, J. } \\
\text { L. (2015) }\end{array}$ & $\begin{array}{l}\text { Cyber Counseling: } \\
\text { Illuminating Benefits and } \\
\text { Challenges }\end{array}$ & $\begin{array}{l}34 \\
\text { undergraduate } \\
\text { students. } \\
\text { Age: } 18 \text { - } 34 \\
\text { Male: } 3 \text {; Female: } \\
31 \\
24 \text { MSW student } \\
\text { interns. } \\
\text { Age: } 20 \text { - } 30 \\
\text { Male: } 2 \text {; Female: } \\
22\end{array}$ & $\begin{array}{l}\text { While student interns } \\
\text { (as counsellors) felt the } \\
\text { lack of body cues to be } \\
\text { thwarting the } \\
\text { counselling process, the } \\
\text { students (clients) felt } \\
\text { that techniques such as } \\
\text { 'emotion bracketing' are } \\
\text { beneficial. }\end{array}$ \\
\hline 16 & $\begin{array}{l}\text { Mishna, F., Bogo, } \\
\text { M., Root, J., \& } \\
\text { Fantus, S. (2014) }\end{array}$ & $\begin{array}{l}\text { Here to Stay: Cyber } \\
\text { Communication as a } \\
\text { Complement in Social } \\
\text { Work Practice }\end{array}$ & $\begin{array}{l}16 \text { counseling } \\
\text { psychology } \\
\text { master students } \\
\text { Age: } 22.58 \text { - } \\
43.25 \\
\text { Male: } 6 \\
\text { Female: } 10\end{array}$ & $\begin{array}{l}\text { The study divided the } \\
\text { participants into co- } \\
\text { facilitating two support } \\
\text { groups: online group } \\
\text { counselling and face-to- } \\
\text { face group counselling. } \\
\text { Participants were novice } \\
\text { counsellors who, from } \\
\text { this study, perceive } \\
\text { more challenges when } \\
\text { conducting online group } \\
\text { counselling. }\end{array}$ \\
\hline 17 & $\begin{array}{l}\text { Nagarajan, M., \& } \\
\text { S, Y. (2019) }\end{array}$ & $\begin{array}{l}\text { Mental health } \\
\text { counsellors' perceptions } \\
\text { on use of technology in } \\
\text { counselling }\end{array}$ & $\begin{array}{l}11 \text { mental health } \\
\text { professionals } \\
\text { Male: } 4 \\
\text { Female: } 7\end{array}$ & $\begin{array}{l}\text { Study conducted show } \\
\text { that the participants, } \\
\text { despite acknowledging } \\
\text { the prevalent use of } \\
\text { technology in } \\
\text { counselling, mostly } \\
\text { prefer one-on-one } \\
\text { modalities due to the } \\
\text { lack of training received } \\
\text { and existed when } \\
\text { compensating the } \\
\text { disadvantages of the } \\
\text { online modalities. }\end{array}$ \\
\hline
\end{tabular}


INTERNATIONAL JOURNAL OF ACADEMIC RESEARCH IN BUSINESS AND SOCIAL SCIENCES Vol. 10, No. 10, 2020, E-ISSN: 2222-6990 @ 2020 HRMARS

\begin{tabular}{|c|c|c|c|c|}
\hline 18 & $\begin{array}{l}\text { Kit, P. L., Wong, } \\
\text { S. S., D'Rozario, } \\
\text { V., \& Teo, C. T. } \\
\text { (2014) }\end{array}$ & $\begin{array}{l}\text { Exploratory Findings on } \\
\text { Novice Group } \\
\text { Counselors' Initial Co- } \\
\text { facilitating Experiences in } \\
\text { In-Class Support Groups } \\
\text { With Adjunct Online } \\
\text { Support Groups }\end{array}$ & $\begin{array}{l}16 \text { counselling } \\
\text { psychology } \\
\text { students. } \\
\text { Age: } 22-44 \\
\text { years } \\
\text { Male: } 6 \\
\text { Female: } 10\end{array}$ & $\begin{array}{l}\text { The research conducted } \\
\text { on } 16 \text { novice counsellors } \\
\text { implied that participants } \\
\text { prefer face-to-face } \\
\text { counselling platform due } \\
\text { to the challenges they } \\
\text { faced in online platform. }\end{array}$ \\
\hline 19 & $\begin{array}{l}\text { Pordelan, } \quad \text { N., } \\
\text { Sadeghi, } \quad \text { A., } \\
\text { Abedi, M. R., \& } \\
\text { Kaedi, M. (2018) }\end{array}$ & $\begin{array}{l}\text { How online career } \\
\text { counseling changes } \\
\text { career development: A } \\
\text { life design paradigm }\end{array}$ & $\begin{array}{l}45 \text { students } \\
\text { divided into } \\
\text { three groups: } \\
\text { online, face-to- } \\
\text { face and control } \\
\text { group } \\
\text { Age: } 20.60 \\
\text { (Mean age) } \\
\text { Male: } 16 \\
\text { Female: } 29\end{array}$ & $\begin{array}{l}\text { The study on online and } \\
\text { offline intervention } \\
\text { groups showed that } \\
\text { both groups are able to } \\
\text { improve and enhance } \\
\text { clients' career } \\
\text { development (which } \\
\text { consists of career } \\
\text { decision-making and } \\
\text { career planning among } \\
\text { many). }\end{array}$ \\
\hline 20 & $\begin{array}{lr}\text { Salleh, } & \text { A., } \\
\text { Hamzah, } & \text { R., } \\
\text { Nordin, } & \text { N., } \\
\text { Ghavifekr, } & \text { S., \& } \\
\text { Joorabchi, } & \text { T. } \\
\text { (2015) } & \end{array}$ & $\begin{array}{l}\text { Online counseling using } \\
\text { email: A qualitative study }\end{array}$ & $\begin{array}{l}6 \text { qualified } \\
\text { counsellors } \\
\text { Age: } 35-49 \\
\text { years } \\
\text { Male: } 3 \text {; Female: } \\
3 \\
59 \text { volunteer } \\
\text { clients } \\
\text { Age: } 20-55 \\
\text { Male: } 12 ; \\
\text { Female: } 47\end{array}$ & $\begin{array}{l}\text { The study showed that } \\
\text { therapeutic } \\
\text { relationships can be } \\
\text { developed through the } \\
\text { online environment } \\
\text { whereby counsellors are } \\
\text { able to adapt some of } \\
\text { the skills they applied in } \\
\text { face-to-face counselling } \\
\text { to online. }\end{array}$ \\
\hline 21 & $\begin{array}{l}\text { Stefan, S., \& } \\
\text { David, D. (2013) }\end{array}$ & $\begin{array}{l}\text { Face-to-Face Counseling } \\
\text { versus High Definition } \\
\text { Holographic Projection } \\
\text { System. Efficacy and } \\
\text { Therapeutic Alliance. A } \\
\text { Brief Research Report }\end{array}$ & $\begin{array}{l}56 \\
\text { undergraduate } \\
\text { Psychology } \\
\text { students. } \\
\text { Age: } 20-44 \text { years } \\
\text { Male: } 7 \\
\text { Female: } 49\end{array}$ & $\begin{array}{l}\text { The study concluded } \\
\text { that no significant } \\
\text { differences are shown in } \\
\text { effectiveness of } \\
\text { reducing distress and } \\
\text { irrational beliefs } \\
\text { (through the use of } \\
\text { theory REBT), as well as } \\
\text { the presence of } \\
\text { therapeutic working } \\
\text { alliance through both } \\
\text { counselling methods. }\end{array}$ \\
\hline
\end{tabular}


INTERNATIONAL JOURNAL OF ACADEMIC RESEARCH IN BUSINESS AND SOCIAL SCIENCES Vol. 10, No. 10, 2020, E-ISSN: 2222-6990 @ 2020 HRMARS

\begin{tabular}{|c|c|c|c|c|}
\hline 22 & $\begin{array}{l}\text { Tse, } \\
\text { Campbell, } \\
\text { Rossen, } \\
\text { Wang, } \\
\text { Jull, A., Yan, E., \& } \\
\text { Jackson, } \\
\text { (2012) }\end{array}$ & $\begin{array}{l}\text { Face-to-Face and } \\
\text { Telephone Counseling } \\
\text { for Problem Gambling }\end{array}$ & $\begin{array}{l}92 \text { participants } \\
\text { who are facing } \\
\text { gambling } \\
\text { problem } \\
\text { Age: } 16 \text { and } \\
\text { above } \\
\text { Male: } 30 \\
\text { Female: } 62\end{array}$ & $\begin{array}{l}\text { The study conducted } \\
\text { online and telephone } \\
\text { counselling towards } \\
\text { participants with } \\
\text { gambling issues. } \\
\text { Findings indicated that } \\
\text { both face-to-face and } \\
\text { telephone intervention } \\
\text { show similar clinical } \\
\text { outcomes for clients } \\
\text { with specific issues. }\end{array}$ \\
\hline
\end{tabular}

\section{Discussion}

The Statistics of Effectiveness and Preferences toward Cyber-Counselling

The statistical or relevant data on the effectiveness and preferences toward cyber-counselling are shown in Table 4.

Table 4. Statistical or relevant data from selected studies

\begin{tabular}{cl}
\hline Literature & \multicolumn{1}{c}{ Statistical or Relevant Data } \\
\hline 1 & $\begin{array}{l}\text { Regardless of gender, there are slightly more preferences toward face- } \\
\text { to-face counselling modalities. }\end{array}$ \\
\hline 3 & $\begin{array}{l}\text { Students show slightly positive or neutral attitudes toward online } \\
\text { counselling. }\end{array}$ \\
\hline 4 & $\begin{array}{l}\text { The use of online counselling in psychotic clients is seen to be less } \\
\text { efficient when related to the lower level of working alliance and } \\
\text { satisfaction as compared to the traditional, offline setting. }\end{array}$ \\
\hline 5 & $\begin{array}{l}\text { There is a lack of, or absence of, evidence of online counselling services } \\
\text { being actively provided at schools in Australia. }\end{array}$ \\
\hline 6 & $\begin{array}{l}\text { Highest score is obtained in career domain issues in cyber-counselling } \\
\text { needs, resulting to high willingness to accept cyber-counseling services } \\
\text { in the said needs. }\end{array}$ \\
\hline 7 & $\begin{array}{l}\text { Most of the respondents who are psychologists and had previously } \\
\text { provided online counselling are more favorable towards using the } \\
\text { online modalities. }\end{array}$ \\
\hline $\begin{array}{l}\text { Online mental health practitioners are showing diverse perceptions on } \\
\text { online clients whereby they are responsible with many different roles in } \\
\text { the counselling relationship. }\end{array}$ \\
\hline 9 & $\begin{array}{l}\text { Email counselling is considered to be as effective as face-to-face } \\
\text { counselling method. }\end{array}$ \\
\hline $\begin{array}{l}\text { 80\% of female and over 84\% of male secondary school students } \\
\text { indicated that they might, or would likely to use online counselling } \\
\text { services if available. }\end{array}$ \\
\hline
\end{tabular}


INTERNATIONAL JOURNAL OF ACADEMIC RESEARCH IN BUSINESS AND SOCIAL SCIENCES Vol. 10, No. 10, 2020, E-ISSN: $2222-6990$ ๑ 2020 HRMARS

\begin{tabular}{|c|c|}
\hline 10 & $\begin{array}{l}\text { Young people are able to develop good therapeutic working alliance } \\
\text { with counsellors through online counselling. }\end{array}$ \\
\hline 11 & $\begin{array}{l}\text { Online counselling is suggested to be provided in conjunction with face- } \\
\text { to-face counselling for more effective outcomes. }\end{array}$ \\
\hline 12 & $\begin{array}{l}\text { Most online counselling clients perceived a significantly stronger } \\
\text { alliance in the Goal subscale analysis than they did in face-to-face } \\
\text { counselling. }\end{array}$ \\
\hline 13 & $\begin{array}{l}\text { Online group counselling is seen to be lacking in social presence as } \\
\text { compared to face-to-face group counselling. }\end{array}$ \\
\hline 14 & $\begin{array}{l}35 \% \text { of the participants are more receptive towards only using online } \\
\text { counselling services. }\end{array}$ \\
\hline 15 & $\begin{array}{l}53 \% \text { out of } 64 \text { undergraduate students participated in the research } \\
\text { chose to receive online counselling. }\end{array}$ \\
\hline 16 & $\begin{array}{l}\text { Participants indicated more preferences toward face-to-face group } \\
\text { counselling than online. }\end{array}$ \\
\hline 17 & $\begin{array}{l}6 \text { out of } 11 \text { participants prefer one-on-one modalities when providing } \\
\text { counselling due to some of the limitations and challenges of the online } \\
\text { setting. }\end{array}$ \\
\hline 18 & $\begin{array}{l}75 \% \text { of the novice counsellors had positive experiences when co- } \\
\text { facilitating online group counselling. }\end{array}$ \\
\hline 19 & $\begin{array}{l}\text { Both online and face-to-face interventions are effective in improving } \\
\text { clients' career development, hence indicating positive outcome for both } \\
\text { counselling modalities. }\end{array}$ \\
\hline 20 & $\begin{array}{l}\text { Therapeutic relationship is able to develop through online } \\
\text { communication. }\end{array}$ \\
\hline 21 & $\begin{array}{l}\text { As small as } 4 \% \text { of differences are shown in the effectiveness and the } \\
\text { presence of therapeutic working alliance via both face-to-face } \\
\text { counselling and videoconference counselling. }\end{array}$ \\
\hline 22 & $\begin{array}{l}\text { Both face-to-face and telephone counselling modalities produce equally } \\
\text { effective short-term clinical outcomes. }\end{array}$ \\
\hline
\end{tabular}

\section{Prevalence of Cyber-Counselling over Face-to-Face Counselling}

According to the reviewed literature readings, it is shown that the use of cyber-counselling is indeed preferred for some, and has the potential to become an alternative counselling method to face-toface counselling. In fact, it is proven that the effectiveness of cyber-counselling is as equal to the more traditional face-to-face counselling with slight or no significant differences (Glasheen, et al., 2016; Dunn, 2012; Stefan, \& David, 2013; Holmes, \& Foster, 2012).

The research conducted on $24 \mathrm{MSW}$ student interns who are providing cyber-counselling services to 24 undergraduate students in a 4 academic years span proved cyber-counselling method to be both benefiting and challenging to counsellor interns and clients for its accessibility, written word or text, emotions conveyed and online disclosure. The undergraduate clients, through this research, reported 
INTERNATIONAL JOURNAL OF ACADEMIC RESEARCH IN BUSINESS AND SOCIAL SCIENCES Vol. 10, No. 10, 2020, E-ISSN: 2222-6990 @ 2020 HRMARS

that cyber-counselling offered them with opportunities to re-read their responses which then enable them to self-reflect.

A different research by Holmes \& Foster (2012) also showed that while online counselling clients show no differences in working alliance from the Task and Bond subscale analyses, they nevertheless showed a stronger alliance towards the Goal subscale analysis. This indicated the ability of telecommunication through computer-assisted communication and as Holmes, \& Foster, (2012) explained, "[the effectiveness of online therapy] in setting agreed upon and clear goals between the counselor and client due to the written nature of the sessions". This is also similar to the research conducted by Stefan \& David (2013) which resulted with the Goal Agreement component to be showing a significant advantage through the use of advanced videoconference system, EON Holopodium. Both researches by Holmes \& Foster (2012) and Stefan \& David (2013) concluded, respectively, that both face-to-face and online counselling are at least equal in their effectiveness in building and forming strong social presence and working alliance, as well as reduction in general distress and irrational beliefs. However, it should also be noted that a study by Blake- Buffini \& Gordon (2014) contradicts to this when the results indicated lower level of working alliance, which is a predicator to lower level of satisfaction, in psychotic clients as compared to the offline or face-toface counselling setting. A study by Holmes \& Kozlowski (2015) on comparison of online and face-toface group counselling also indicated that despite the improved of social presence through the use of videoconferencing, participants nevertheless perceived a lack of social presence and emotional relatedness in online group counselling as compared to the more traditional modalities.

Nevertheless, the research conducted using the CBT approach (Barak et al., 2008, Stefan \& David, 2013), also demonstrated the effectiveness of online interventions on clients with disorders such as panic, anxiety, PTSD and smoking cessation. Glasheen, et al., (2016) showed that young people facing severe psychological distress are more inclined in using online counselling as a medium for helpseeking. The very foundation of anonymity and privacy in online counselling services are most likely the reasons that they prefer to seek help through online communication, hence making such method as powerful tool in overcoming the 'negation effect' (Rickwood, et al. 2005; Glasheen, et al., 2016). This is also consistent with a study by Nagarajan \& Yuvaraj (2019) whereby counsellors perceive anonymity, convenience and accessibility to be important factors that attract online clients.

A research on males suffering from addictions also implied that online counselling may be more preferable to them for the sense of anonymity and privacy that the online method offered them with (Campbell \& Glasheen, 2012). In fact, this sense of anonymity has become one of the main benefits that online counselling possesses, where it gives more control to the clients especially for those who are facing the feeling of embarrassment when experiencing face-to-face therapy (Campbell \& Glasheen, 2012; Hanley, 2012). Hence, it is to no surprise that the 'disinhibitation effect' offered in online counselling enables clients to develop a more open, intimate and personal counselling relationship (Campbell \& Glasheen, 2012; Glasheen, et al., 2016).

Apart from that, a research conducted by Lan (2016) illustrated that students with disabilities in universities in Taiwan are displaying more cyber-counselling needs on issues in domains such as career, academic achievements; subsequently, this influences them to have high willingness to 
INTERNATIONAL JOURNAL OF ACADEMIC RESEARCH IN BUSINESS AND SOCIAL SCIENCES Vol. 10, No. 10, 2020, E-ISSN: 2222-6990 @ 2020 HRMARS

choose and seek for cyber-counselling services, given that they have high counselling attitudes. It should also be noted however that a different study by Glasheen, et al., (2016) and Campbell \& Glasheen (2012) reported that students at secondary schools would be more likely to seek for career counselling through face-to-face counselling and instead seek for online counselling for more sensitive, personal and complex issues or concerns such as sexuality, suicide ideation, sexual assault and other stigmatized issues. This is supported in a research by Mishna, et al., (2015) who explained the issues being discussed through cyber counselling services to be different and more sensitive than those discussed in face-to-face counselling method. Different studies by Ballesteros and Hilliard (2016), and Blake-Buffini \& Gordon (2014) also agreed on how positive attitudes of US-based Latina/o college students and Korean college students, respectively, toward online counselling are due to less self-stigma and stigma as perceived by others on this counselling modalities.

Online individual approaches and interventions also appeared to be more effective and best be utilized by the young (19 - 24) and older adults (25 - 39) (Barak et al., 2008; Stefan \& David, 2013). This is not at all a shocking finding since the use of ICT is far-reaching and prevalent among people of such age group. Roy \& Gillett (2008) also described, as quoted in Dunn (2012), "a single case-study where email communication enabled a 17-year-old female client with severe and enduring depression, who had previously been unable to form an alliance through face-to-face contact, to engage effectively with a psychiatrist". This showed that in addition to young age, factors such as anonymity, disinhibition, locus of control, permanent record, opportunities for self-monitoring and asynchronous responses in online counselling method may be facilitative in the counselling process (Dunn, 2012).

\section{Patterns of Factors That Make Prevalent of Cyber-Counselling as Alternative and Preferable Method of Counselling}

The myriad prevalence of cyber-counselling method as stated in subtopic 5.2 has listed some of the factors that make online method and interventions preferable and more attractive to some. These unique advantages that online counselling method has over other counselling methods are those such as better accessibility, opportunity for self-reflect and self-monitor through written word or text, better counselling goal agreement, anonymity and privacy, and sense of control. The disinhibition component in online space also create more opportunities for clients to discuss different and more complex, sensitive and personal issues than those discussed in face-to-face counselling, hence showing less worry to the issue social stigma. Lastly, the negation effect that most young people or people with severe issues faced is able to be mitigated when online counselling method is offered in addition to, or in place of the more traditional counselling method that may be too daring and intimidating to some.

\section{Limitations of Cyber-Counselling as Compared to Face-to-Face Counselling}

Studies showed that online counselling are, sometimes, not the best solution for some clients, and even counsellors (Wong et al., 2018). Through online counselling conducted, counsellors expressed difficulties in eliciting emotional responses from clients, which restrict their abilities to show empathy, one of the core components to being an effective and therapeutic counsellor. Hence, the lack of non-verbal cues and body language from both parties, clients and counsellors, are possibly the main reason that online counselling are less preferred, or limited in their efficiencies when 
INTERNATIONAL JOURNAL OF ACADEMIC RESEARCH IN BUSINESS AND SOCIAL SCIENCES Vol. 10, No. 10, 2020, E-ISSN: 2222-6990 @ 2020 HRMARS

compared to face-to-face counselling. Also according to Dowling \& Rickwood (2014), although the sense of anonymity and control of the online setting are attracting more online clients, online mental health practitioners are facing difficulties in extracting or gaining specific information from clients due to the more control that they have over the counselling relationship.

The research conducted, as reported by Mishna, et al., (2015), also demonstrated the conflicting perspectives of MSW student interns and undergraduate student clients toward emotions conveyed through the use of cyber in counselling. Although the majority of clients expressed techniques such as emotions bracketing to be meaningful as it enables them to feel understood by their counsellors, the MSW student interns were otherwise felt the lack of or inability to capture nonverbal communications from clients to be thwarting their ability to connect more deeply. Studies by Campbell and Glasheen (2012);Cipolletta and Mocellin (2017) also agreed to this, where they implied that counsellors and psychologists are concerned with the absence of eye contact, voice tone, facial expression and body language which will undermine the effectiveness and the therapeutic process in the counselling relationship.

Result from a study by Lan (2016) also indicated that students with hearing disorders and low grades show low tendencies and willingness to use cyber-counselling services. Similar study conducted also showed that students who are not well acquainted with using computers indicated low willingness in using cyber-counselling services. This pattern of behavior can also be seen in counsellors, psychologists and other mental health practitioners through a study by Cipolletta \& Mocellin (2017) that stated frustration towards technical problems in online setting acts as a barrier to online counselling. This is also supported by Campbell \& Glasheen (2012) who stated that school counsellors are restricted from providing online counselling to students at school due to the lack of training in the use of ICT and other new technologies, hence causing more challenges for online practitioners to constantly and efficiently provide such services. This is consistent with a study by Nagarajan \& Yuvaraj (2019) where the participants, who are mental health professionals, commented on the "dearth in training for online counselling", and a lack of technical skills and skills that are specific to online services.

\section{Implication}

Although the more traditional, gold standard and more preferred treatment (Wong et al., 2018) through face-to-face counselling services are usually sought after, it should not be overlooked on how online counselling can potentially reach out to individuals who may not have the time or physical needs to seek for face-to-face counselling. As Wong et al. (2018) stated, "the more mental health providers understand the forces motivating people to seek help, or not, the better they can do in assuring that those in need of help are able to obtain it".

As the youth and adolescents have the tendency to seek for help and gain information online, it is only reasonable that online counselling should be expanded and enhanced on its delivery and accessibility to all. In Australia, 'youth friendly' websites have been built with the purpose of spreading and providing therapeutic information to the young people through the use of FAQs, fact sheets and suggested links (Glasheen, et al., 2016). However, despite the focal use of technology and online space nowadays, less research are conducted on the use of online counselling among the 
young people as compared to other age group. This is supported by Campbell \& Glasheen (2012) who highlighted the lack of research on the use of online counselling services at schools as compared to those researches conducted on college and university students. As Green (2006) stated, quoted in Hanley (2012), "such a gap in the literature is indicative of the 'neglect' of the alliance in youth counselling in general".

One of the five themes extracted also mentioned on the need of online counselling skills to compensate for the lack of nonverbal messages which are prevalent in face-to-face counselling, but not to online counselling method (Campbell \& Glasheen ,2012),. Another theme, from the same study, also implied that school counsellors are concerned about the uncontrollable boundaries between clients and counsellors in the online services where they perceived that students would have the freedom to contact the counsellors at any time. This hence calls for more research on the matter of the use of online counselling so that more people, both counsellors and possible clients, are exposed to, and are well informed with the myriad use and effectiveness of such counselling method.

According to Stefan \& David (2013), few researches has been made on the use of online counselling via video conference in spite of its potential in enhancing the physical presence and compensating for the lack of body language. The same research conducted by Stefan \& David (2013) utilized the EON Holopodium which is an advanced videoconference system that has never been used for counselling purposes before but was tested in this research and proven its effectiveness in improving clients' distress and irrational beliefs, as well as enhancing therapeutic working alliance in the counselling relationship. Hence for this particular reason, more researchers and counsellors are also needed to shift their focus on the use of online interactive tools in cyber-counselling to improve the overall counselling experiences in clients. Nevertheless, it should also be noted on how some other studies also indicated online counselling to be not as effective as the offline modality which hence calls for more attention to this matter in order to improve the overall clients' counselling experiences. A study by Harris \& Birnbaum (2014) suggests online counselling to be provided in conjunction with face-to-face counselling in an effort to overcome barriers faced by both counselling modalities.

Online counselling method is seen to be limited in its use due to the lack of training for counsellors to conduct efficient online services. This is affirmed by Mishna et al., (2015), who stresses on the "lack of educational programs to prepare social work students [counsellors and therapists included] to effectively use ICT as practitioners. Therefore, there is a dire need for counsellors to be fully prepared for the use of online counselling method through courses in development of appropriate skills that can compensate for the lack of visual, auditory and body communication cues so to ensure that therapeutic counselling relationship is attained (Campbell \& Glasheen, 2012). This is in addition to the appropriate set of counselling skills and techniques such as the 'emotion bracketing' that need to be developed and refined for better delivery in online counselling.

Overall, the literature readings reviewed have demonstrated many compelling data that shows the unique advantages, and challenges, the online counselling method offered us with. It was obvious that, during the searching process, research on cyber counselling was limited, which consequently influenced the validity and reliability of the studies reviewed. The numbers of participants involved 
in some studies conducted were also small in comparison with others which may inadvertently invite the possibility for biasness and inaccurate data obtained. Hence, it is important for counsellors themselves to be advocates on the use of online counselling as alternative to counselling methods and at the same time is properly trained in acquiring skills and techniques to provide such services. Apart from that, more in-depth research on the topic are needed for future references. The lack of literatures found on the topic of online counselling and face-to-face counselling may possibly require a wider research for reviewer. Hence, asides from the need for more research on the effectiveness and improvement of the online counselling method, more thorough and wider search need to also be conducted in order to obtain as many data possible so that accurate and reliable review and analysis from the literatures can be done.

\section{Conclusion}

The use of ICT nowadays is ubiquitous and eminent among not just the youth and adolescents, but also the adults and older generations in all parts of the world. Along with this continual modernization, the counselling field, more specifically cyber-counselling, has also paved its way into finding more and more alternatives in order to provide and deliver the best counselling services to all clients with issues unique to them. From the literatures reviewed, reviewer was able to discover the prevalence, or factors that are influencing the preferences of specific group of people toward online counselling. In general, the effectiveness of online counselling is at least as equal to that of face-to-face counselling while the features that the online method offered clients with are able to attract people who may initially did not consider seeking help through the more traditional, face-toface counselling. While there are many advantages of online counselling, there are, of course, limitations that are restricting its use and delivery method which explains a fraction of clients and counsellors who prefer the more conventional method in counselling. To conclude, the comparable effectiveness of online counselling to face-to-face counselling is influencing the preferences toward using online counselling, hence implying the prevalence of online counselling as an alternative method to counselling.

The result of this research can be contributing to Malaysia researcher who interests with online counselling approach. It helps them in enhancing knowledge and information. The findings of this research can create awareness for Malaysian researcher to pay more concern on online counselling. So, this research can be a reference and guidance for future research where the focus in Malaysia context. Besides, the findings of this research give counsellors another sight towards online counselling. These findings are important to enable counsellors to make decisions in expanding their network of services by offering e-counselling services. This online counselling service can extend the time of counsellor service. Client and counsellor can freely to getting their counselling service without exposing themselves. Besides, it expends the reach out of counsellors and clients.

\section{Acknowledgement}

This research is funded under Grant FRGS 2018 (5540082) under Ministry of Education, Malaysia.

\section{References}

Al-krenawi, A., Graham, J. R., Al-bedah, E., Kadri, H. M., and Sehwail, M. A. (2009). Cross-national comparison of middle eastern university students: help-seeking behaviors, attitudes toward 
INTERNATIONAL JOURNAL OF ACADEMIC RESEARCH IN BUSINESS AND SOCIAL SCIENCES

Vol. 10, No. 10, 2020, E-ISSN: 2222-6990 @ 2020 HRMARS

helping professionals, and cultural beliefs about mental health problems. Commun. Mental Health J. 45, 26-36. https://doi.org/10.1007/s10597-008-9175-2

Ballesteros, J. L., \& Hilliard, R. C. (2016). U.S.-Based Latina/O College Students' Attitudes toward Online Counseling. International Journal for the Advancement of Counselling, 38(4), 269-285. https://doi.org/ 10.1007/s10447-016-9271-x

Barak, A., Hen, L., Boniel-Nissim, M., and Shapira, N. (2008). A comprehensive review and a metaanalysis of the effectiveness of internet-based psychotherapeutic interventions. J. Technol. Hum. Serv. 26, 109-160. https://doi.org/ 10.1080/15228830802094429

Bathje, G. J., Kim, E., Rau, E., Bassiouny, M. A., \& Kim, T. (2014). Attitudes toward Face-to-Face and Online Counseling: Roles of Self-Concealment, Openness to Experience, Loss of Face, Stigma, and Disclosure Expectations among Korean College Students. International Journal for the Advancement of Counselling, 36(4), 408-422. https://doi.org/ 10.1007/s10447-0149215-2

Blake-Buffini, K., \& Gordon, M. (2014). One-to-one support for crisis intervention using online synchronous instant messaging: evaluating working alliance and client satisfaction. British Journal of Guidance \& Counselling, 43(1), 105-116. https://doi.org/ 10.1080/03069885.2014.987723

Campbell, M. A., \& Glasheen, K. (2012). The provision of online counselling for young people. In B. Popoola, \& O. Adebowale (Eds.). Online Guidance and Counseling: Toward Effectively Applying Technology (pp 1-13). Information Science Reference, USA: Hershey PA.

Cipolletta, S., \& Mocellin, D. (2018). Online counseling: An exploratory survey of Italian psychologists' attitudes towards new ways of interaction. Psychotherapy Research, 28(6), 909-924. https://doi.org/ 10.1080/10503307.2016.1259533

Dowling, M. J., \& Rickwood, D. J. (2014). Experiences of Counsellors Providing Online Chat Counselling to Young People. Australian Journal of Guidance and Counselling, 24(02), 183196. https://doi.org/ 10.1017/jgc.2013.28

Dunn, K. (2012). A qualitative investigation into the online counselling relationship: to meet or not to meet, that is the question. Counselling and Psychotherapy Research, 12(4). 316-326. https://doi.org/ 10.1080/14733145.2012.669772

Eisenberg, D., Golberstein, E., and Gollust, S. E. (2007). Help-seeking and access to mental health care in a university student population. Med. Care. 45, 594-601. https://doi.org/ 10.1097/MLR.0b013e31803bb4c1

Glasheen, K. J., Shochet, I., \& Campbell, M. A. (2016). Online counselling in secondary schools: would students seek help by this medium? British Journal of Guidance and Counselling, 44(1), 108-122. https://doi.org/10.1080/03069885.2015.1017805

Harris, B., \& Birnbaum, R. (2014). Ethical and Legal Implications on the Use of Technology in Counselling. Clinical Social Work Journal, 43(2), 133-141. https://doi.org/ 10.1080/03069885.2015.1017805

Hanley, T. (2012). Understanding the online therapeutic alliance through the eyes of adolescent service users. Counselling and Psychotherapy Research, 12(1). 35-43. https://doi.org/ 10.1080/14733145.2011.560273

Heflinger, C. A., \& Hinshaw, S. P. (2010). Stigma in child and adolescent mental health services research: understanding professional and institutional stigmatization of youth with mental 
INTERNATIONAL JOURNAL OF ACADEMIC RESEARCH IN BUSINESS AND SOCIAL SCIENCES

Vol. 10, No. 10, 2020, E-ISSN: 2222-6990 @ 2020 HRMARS

health problems and their families. Adm. Policy Ment. Health. 37, 61-70.

https://doi.org/10.1007/s10488-010-0294-z

Holmes, C. M., \& Kozlowski, K. A. (2015). A Preliminary Comparison of Online and Face-to-Face Process Groups. Journal of Technology in Human Services,33(3), 241-262. https://doi.org/ 10.1080/15228835.2015.1038376

Holmes, C., \& Foster, V. (2012). A preliminary comparison study of online and face-to-face counseling: Client perceptions of three factors. Journal of Technology in Human Services, 30, 14-31. https://doi.org/ 10.1080/15228835.2012.662848

Lan, C. M. (2016). Predictors of willingness to use cyber counseling for college students with disabilities. Disability and Health Journal, 9, 346-352. https://doi.org/ 10.1016/j.dhjo.2015.11.004

Mishna, F., Bogo, M., \& Sawyer, J. L. (2015). Cyber counseling: Illuminating benefits and challenges. Clinical Social Work Journal, 43(2), 169-178. https://doi.org/10.1007/s10615-013-0470-1

Mishna, F., Bogo, M., Root, J., \& Fantus, S. (2014). Here to Stay: Cyber Communication as a Complement in Social Work Practice. Families in Society: The Journal of Contemporary Social Services, 95(3), 179-186.https://doi.org/ 10.1606/1044-3894.2014.95.23

Murphy, L., Parnass, P., Mitchell, D. L., Hallett, R., Cayley, P., \& Seagram, S. (2009). Client satisfaction and outcome comparisons of online and face-to-face counselling methods. British Journal of Social Work, 39, 627-640. https://doi.org/10.1093/bjsw/bcp041

Nagarajan, M., \& Yuvaraj, S. (2019). Mental health counsellors' perceptions on use of technology in counselling. Current Psychology. 1-7. https://doi.org/10.1007/s12144-018-0104-4

Kit, P. L., Wong, S. S., D’Rozario, V., \& Teo, C. T. (2014). Exploratory findings on novice group counselors' initial co-facilitating experiences in in-class support groups with adjunct online support groups. The Journal for Specialists in Group Work, 39(4), 316-344. https://doi.org/ 10.1080/01933922.2014.954737

Pordelan, N., Sadeghi, A., Abedi, M. R., \& Kaedi, M. (2018). How online career counseling changes career development: A life design paradigm. Educational Information Technologies. 23, 26552672. https://doi.org/10.1007/s10639-018-9735-1

Rickwood, D., Deane, F. P., Wilson, C. J., \& Ciarrochi, J. V. (2005). Young people's help-seeking for mental health problems. Australian e-Journal for the Advancement of Mental Health, 4 (3), 1-34. https://doi.org/ 10.5172/jamh.4.3.218

Salleh, A., Hamzah, R., Nordin, N., Ghavifekr, S., \& Joorabchi, T. N. (2015). Online counseling using email: A qualitative study. Asia Pacific Education Review,16(4), 549-563. https://doi.org/ 10.1007/S12564-015-9393-6

Stefan, S., \& David, D. (2013). Face-to-face counseling versus high definition holographic projection system. Efficacy and therapeutic alliance. A brief research report. Journal of Cognitive \& Behavioral Psychotherapies, 13(2), 299-307.

Suzuki, L. K., \& Calzo, J. P. (2004). The search for peer advice in cyberspace: An examination of online teen bulletin boards about health and sexuality, Journal of Applied Developmental Psychology. 25 (6), 685-698. https://doi.org/ 10.1016/j.appdev.2004.09.002

Tse, S., Campbell, L., Rossen, F., Wang, C. W., Jull, A., Yan, E., \& Jackson, A. (2012). Face-to-Face and Telephone Counseling for Problem Gambling. Research on Social Work Practice, 23(1), 5765. https://doi.org/10.1177/1049731512466150 
INTERNATIONAL JOURNAL OF ACADEMIC RESEARCH IN BUSINESS AND SOCIAL SCIENCES Vol. 10, No. 10, 2020, E-ISSN: 2222-6990 @ 2020 HRMARS

Wong, K. P., Bonn, G., Tam, C. L., \& Wong, C. P. (2018). Preferences for online and/or face-to-face counseling among university students in Malaysia. Frontiers in Psychology, 9, 64. https://doi.org/ 10.3389/fpsyg.2018.00064

Zainudin, Z. N., \& Yusop, Y. M. (2018). Client's Satisfaction in Face-To-Face Counselling and Cyber Counseling Approaches: A Comparison. International Journal of Academic Research in Business and Social Sciences, 8(3), 677-684. http://dx.doi.org/10.6007/IJARBSS/v8-i3/3992 